\title{
Operation-relevant modeling of an experimental proton exchange membrane fuel cell
}

\author{
Ai-Jen Hung ${ }^{\mathrm{a}}$, Lung-Yu Sung ${ }^{\mathrm{b}}$, Yih-Hang Chen ${ }^{\mathrm{b}}$, Cheng-Ching $\mathrm{Yu}^{\mathrm{a}, *}$ \\ a Department of Chem. Eng., National Taiwan University, Taipei 106-17, Taiwan \\ ${ }^{\mathrm{b}}$ Energy \& Environmental Lab., Industrial Technology Research Institute, Hsinchu 310, Taiwan \\ Received 26 April 2007; received in revised form 30 May 2007; accepted 4 June 2007 \\ Available online 23 June 2007
}

\begin{abstract}
A current-voltage $(I-V)$ curve, also known as a polarization curve, is generally used to express the characteristics of a proton exchange membrane (PEM) fuel cell system. The behavior of a PEM fuel cell is highly nonlinear and it is important to incorporate process nonlinearity for control system design and process optimization. Therefore, it is essential to generate the $I-V$ curve from the model as the operating condition changes. A first principle one-dimensional water and thermal management model is developed to generate the $I-V$ curve. The model considers the effects of water transport across the membrane, activation overpotential, ohmic overpotential, concentration overpotential, pressure drops, and current density distribution along the channel of a PEM fuel cell. Design and modeling parameters are obtained via regression from four sets of experimental data. They are further validated as operating conditions (e.g., fuel cell temperature, anode pressure, cathode pressure, hydrogen stoichiometric ratio, air stoichiometric ratio, hydrogen humidification temperature, and air humidification temperature) change. A sensitivity analysis example is used to illustrate the usefulness of the predictive model.
\end{abstract}

(C) 2007 Elsevier B.V. All rights reserved.

Keywords: Proton exchange membrane fuel cell; $I-V$ curve; Modeling; Optimization

\section{Introduction}

The depletion of the world's fossil fuel reserves has led to renewed interest in fuel cell systems. In the last decade, a large amount of research has resulted in significant progress in power generation using fuel cell systems. The proton exchange membrane (PEM) fuel cell, in particular, has drawn more attention due to its quick start-up, high efficiency and lack of pollution. The PEM fuel cell is an efficient and clean power source, which is being developed for both stationary and mobile applications. It uses a simple chemical reaction to combine hydrogen and oxygen producing water and heat, generating power in the process.

A PEM fuel cell is an electrochemical energy converter where no combustion occurs during the reaction. In order to design and optimize the PEM fuel cell, it is very important to determine the polarization curve, which shows the performance characteristics of the fuel cell. As soon as the $I-V$ curve is determined,

\footnotetext{
* Corresponding author. Tel.: +8862 3366 3037; fax: +886223623040.

E-mail address: ccyu@ @ntu.edu.tw (C.-C. Yu).
}

other information about the fuel cell becomes obtainable, such as power output and efficiency which can be used as a design and control indicator. Appropriate water and thermal management plays a crucial role in the fuel cell operation. This is because too much water will cause flooding and too little water will cause the membrane dry out, both conditions will lead to cell operation failure. To maintain the operating cell temperature, heat as a by-product generated by the electrochemical reaction must be controlled by a cooling system otherwise excessive heat will also result in cell failure.

Over the last few years, many studies on modeling a PEM fuel cell have been developed. In one-dimensional models, Springer et al. [1] were the first to consider and analyze water transport mechanism within the membrane and its effect on the cell performance. Moreover, various factors that could reduce the cell performance have been investigated in refs. [2-5]. In particular, Yi and Nguyen [3] proposed the along-the-channel model to explore effects of design and operating parameters. Water and thermal management of a PEM fuel cell using two-dimensional models have been studied in refs. [6-10]. More recently, a comprehensive three-dimensional model of transport phenomena in 


\begin{tabular}{|c|c|}
\hline \multicolumn{2}{|c|}{ Nomenclature } \\
\hline$a$ & water vapor activity \\
\hline C & $\begin{array}{l}\text { concentration at the surface of the membrane } \\
\left(\mathrm{mol} \mathrm{cm}^{-3}\right)\end{array}$ \\
\hline$d$ & channel height $(0.08 \mathrm{~cm})$ \\
\hline$D^{*}$ & $\begin{array}{l}\text { diffusion coefficient of water in the membrane } \\
\left(\mathrm{cm}^{2} \mathrm{~s}^{-1}\right)\end{array}$ \\
\hline$D_{\mathrm{e}}$ & hydraulic diameter $(\mathrm{cm})$ \\
\hline$D_{\mathrm{H}_{2}}$ & $\begin{array}{l}\text { hydrogen diffusion coefficient in diffusion layer } \\
\left(10^{-6} \mathrm{~cm}^{2} \mathrm{~s}^{-1}\right)\end{array}$ \\
\hline$D_{o}$ & $\begin{array}{l}\text { intra-diffusion coefficient of water in membrane } \\
\left(5.5 \times 10^{-7} \mathrm{~cm}^{2} \mathrm{~s}^{-1}\right)\end{array}$ \\
\hline$D_{\mathrm{O}_{2}}$ & $\begin{array}{l}\text { oxygen diffusion coefficient in diffusion layer } \\
\left(10^{-6} \mathrm{~cm}^{2} \mathrm{~s}^{-1}\right)\end{array}$ \\
\hline$D_{\mathrm{w}}$ & $\begin{array}{l}\text { water diffusion coefficient in diffusion layer } \\
\left(10^{-6} \mathrm{~cm}^{2} \mathrm{~s}^{-1}\right)\end{array}$ \\
\hline$f$ & friction factor \\
\hline$F$ & Faraday's constant $\left(96,485 \mathrm{C} \mathrm{mol}^{-1}\right)$ \\
\hline$g_{\mathrm{c}}$ & conversion factor $\left(1 \mathrm{~kg} \mathrm{~m} \mathrm{~N}^{-1} \mathrm{~s}^{-2}\right)$ \\
\hline$h$ & channel width $(0.2 \mathrm{~cm})$ \\
\hline$I$ & $\begin{array}{l}\text { local current density along the channel length } \\
\left(\mathrm{Acm}^{-2}\right)\end{array}$ \\
\hline$I_{\text {avg }}$ & average current density $\left(\mathrm{A} \mathrm{cm}^{-2}\right)$ \\
\hline$I_{0}$ & exchange current density $\left(\mathrm{A} \mathrm{cm}^{-2}\right)$ \\
\hline$k_{\mathrm{c}}$ & condensation rate constant $\left(\mathrm{s}^{-1}\right)$ \\
\hline$k_{\mathrm{p}}$ & water permeability $\left(\mathrm{cm}^{2}\right)$ \\
\hline$L$ & channel length $(67.2 \mathrm{~cm})$ \\
\hline$M$ & molar flow rate $\left(\mathrm{mol} \mathrm{s}^{-1}\right)$ \\
\hline$n_{\mathrm{d}}$ & $\begin{array}{l}\text { electro-osmotic coefficient of water in membrane } \\
\text { (water molecules per proton) }\end{array}$ \\
\hline$P$ & pressure (atm) \\
\hline$R$ & gas constant $\left(8.314 \mathrm{~J} \mathrm{~mol}^{-1} \mathrm{~K}^{-1}\right)$ \\
\hline$t_{\mathrm{m}}$ & membrane thickness $(\mathrm{cm})$ \\
\hline$T_{\text {cell }}$ & cell temperature $(\mathrm{K})$ \\
\hline$v$ & average velocity $\left(\mathrm{cm} \mathrm{s}^{-1}\right)$ \\
\hline$V_{\text {cell }}$ & cell voltage $(\mathrm{V})$ \\
\hline$V_{\mathrm{oc}}$ & open circuit potential $(\mathrm{V})$ \\
\hline$W_{\mathrm{m}, \mathrm{dry}}$ & dry membrane weight $\left(\mathrm{g} \mathrm{mol}^{-1}\right)$ \\
\hline$Y$ & mole fraction \\
\hline \multicolumn{2}{|c|}{ Greek letters } \\
\hline$\alpha$ & transfer coefficient (water molecule per proton) \\
\hline$\delta$ & diffusion layer thickness $(\mathrm{cm})$ \\
\hline$\mu$ & water viscosity $\left(3.565 \times 10^{-3} \mathrm{~g} \mathrm{~cm}^{-1} \mathrm{~s}^{-1}\right)$ \\
\hline$\rho$ & density $\left(\mathrm{g} \mathrm{cm}^{-3}\right)$ \\
\hline$\rho_{\mathrm{m}, \mathrm{dry}}$ & dry membrane density $\left(2 \mathrm{~g} \mathrm{~cm}^{-3}\right)$ \\
\hline & membrane conductivity $\left(\mathrm{cm}^{-1} \mathrm{Ohm}^{-1}\right)$ \\
\hline \multicolumn{2}{|c|}{ Subscripts } \\
\hline $\mathrm{a}$ & anode \\
\hline $\mathrm{c}$ & cathode \\
\hline $\mathrm{w}$ & water \\
\hline \multicolumn{2}{|c|}{ Superscripts } \\
\hline & saturation \\
\hline $\mathrm{v}$ & vapor \\
\hline
\end{tabular}

a PEM fuel cell has been developed and implemented into a commercial computational fluid dynamics (CFD) package in refs. [11-13]. The effect of temperature has been incorporated in three-dimensional and steady-state model in refs. $[14,15]$.

The objective of this work is to find a simplest possible predictive model for PEM fuel cell behavior description under various operating conditions. First, a one-dimensional water and thermal management model [3] has been adopted to generate the $I-V$ curve. Instead of modeling a single operating temperature, the parameters have been adjusted to describe fuel cell behavior at different operating conditions. Then, two modeling parameters (activation energy from ref. [6] and diffusion layer thickness from ref. [16]), two design parameters from ref. [1] (open circuit voltage and membrane thickness), are obtained by minimizing the square errors between experiments and predictions for four sets of experimental data. Next, the model is further validated experimentally under various operating conditions. Finally, the prediction capability of the model is illustrated via sensitivity analyses. The effects of these parameters, such as the cell temperatures, the reactant flow rates, the humidity of the reactant gases, and the pressures at the anode and cathode on the cell performance have been investigated to describe fuel cell performance and then to determine the optimum operating conditions.

\section{Experimental}

The experiments on a single fuel cell were performed at the Industrial Technology Research Institute/Energy and Environment Research Laboratory (ITRI/EEL) facility in Hsin Chu. An experimental single fuel cell is composed of several components: end plates, current connector plates, membrane electrode assembly (MEA), gas diffusion layer, flow field plate, locating pins, and gas feed connection. The assembled experimental device of a PEM fuel cell is $50 \mathrm{~mm} \times 50 \mathrm{~mm}$. A $100 \mathrm{~mm} \times 100 \mathrm{~mm}$ bipolar plate is made of carbon graphite with two channels, each $1 \mathrm{~mm}$ wide, $1 \mathrm{~mm}$ deep and a total of $672 \mathrm{~mm}$ in length. There is $1 \mathrm{~mm}$ shoulder between the two channels to prevent deformation of the membrane electrode assembly. The channels' configurations are serpentine. The active area of the MEA provided by Gore-Tex Inc. using PRIMEA ${ }^{\mathrm{TM}} 5621$ is $50 \mathrm{~mm} \times$ $50 \mathrm{~mm}$.

The temperature of the cell is controlled by an electrical heating device as shown in Fig. 1. Pure hydrogen as a fuel is fed to the anode side and air as an oxidant is fed to the cathode side. The stoichiometric ratios (which are the molar ratios between the actual flow rate of a reactant and the theoretical flow rate according to reaction stoichiometry) of these two flow rates are kept constant. The flow rates of the reactant gases are controlled by mass flow controllers. Both gas flows go through humidifiers before entering the PEM fuel cell and the water vapor content in the reactant gases are adjusted and controlled by adjusting the humidifier temperature via corresponding temperature controllers. The PEM fuel cell consists of two gas channels separated by the MEA. On the surface of the anode and cathode sides of the MEA, the electrochemical reaction takes place. The flow rates of the outlet gases are modulated by backpressure regula- 


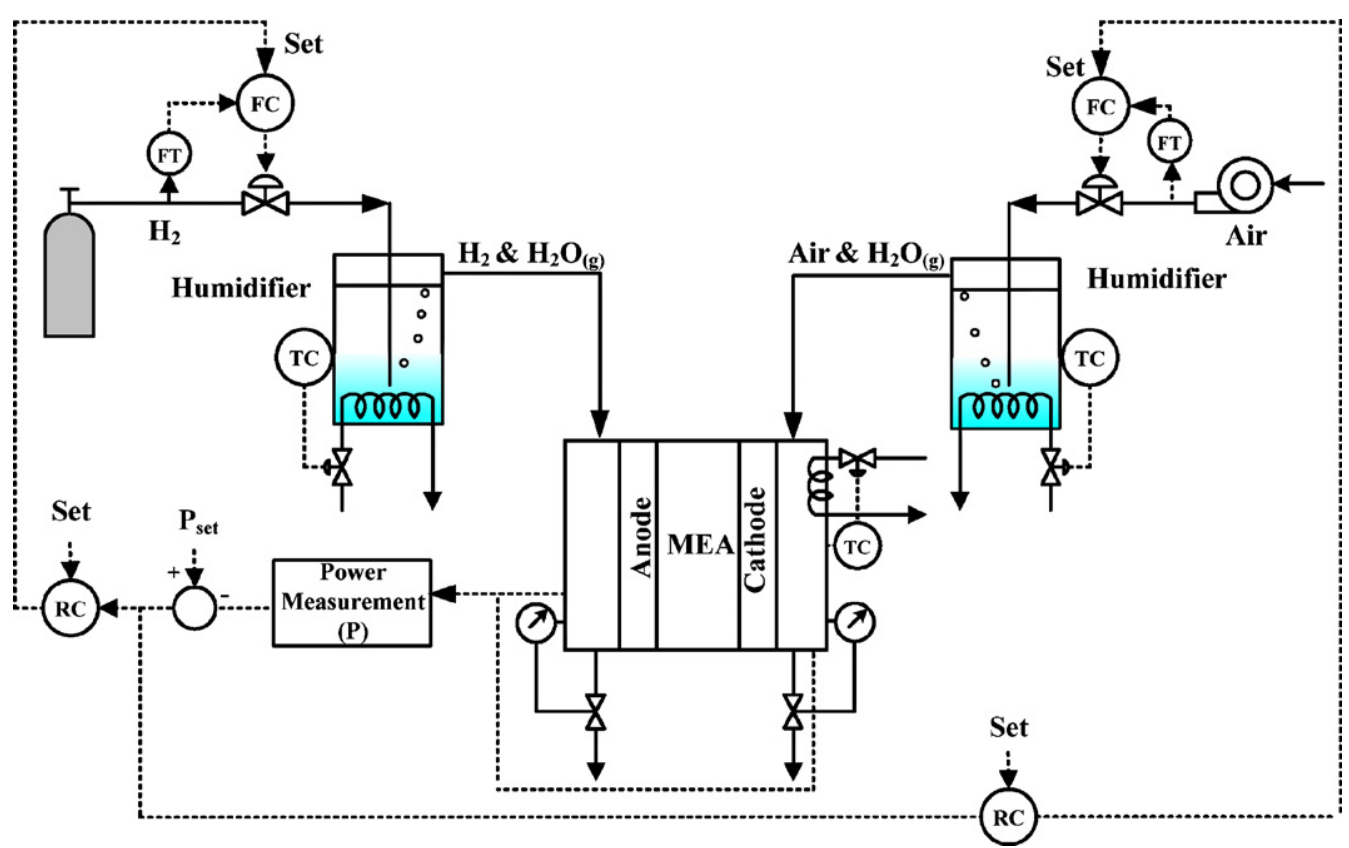

Fig. 1. Schematic of the experimental setup showing FT (flow transmitter), FC (flow controller), RC (ratio controller), TC (temperature controller), Set (set-point), and $P_{\text {set }}$ (power set-point).

tors to keep the pressure along the channels fixed. Then power output is produced and the electronic load bank is used to measure the power to adjust the input flow rates, water and heat are by-products. During the experiments, the cell voltage is set to a constant value for each operating condition, the feed flow rates are changed to match the required power level. Thus, $I-V$ curves at different operating temperatures were generated as shown in Fig. 2.

\section{Steady-state model of a PEM fuel cell}

With the experimental $I-V$ curve, a first principle model can be constructed for operation. Here, a one-dimensional water and thermal management model of [3] is used for behavior description.

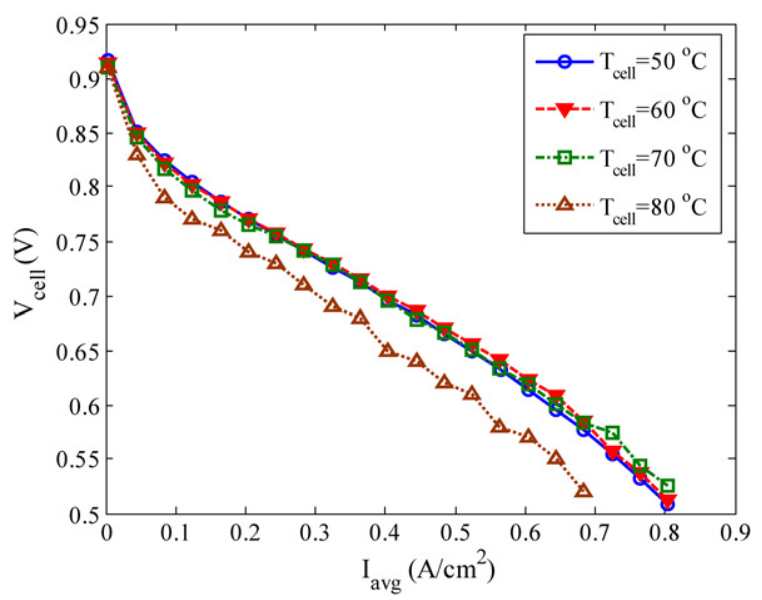

Fig. 2. Experimental results of four different cell temperatures.

\subsection{Model assumptions}

Assumptions made are:

(1) ideal gas behavior,

(2) plug-flow in the flow channel,

(3) quasi-steady-state for all the conservation equations,

(4) considering only $x$-direction not $y$-direction (Fig. 3; the membrane is much thinner than the length of the flow channel) and separating the length of the flow channel ( $x$ direction) into several sections and each of them is assumed to be a CSTR (continuous stirred tank reactor),

(5) constant fuel cell temperature.

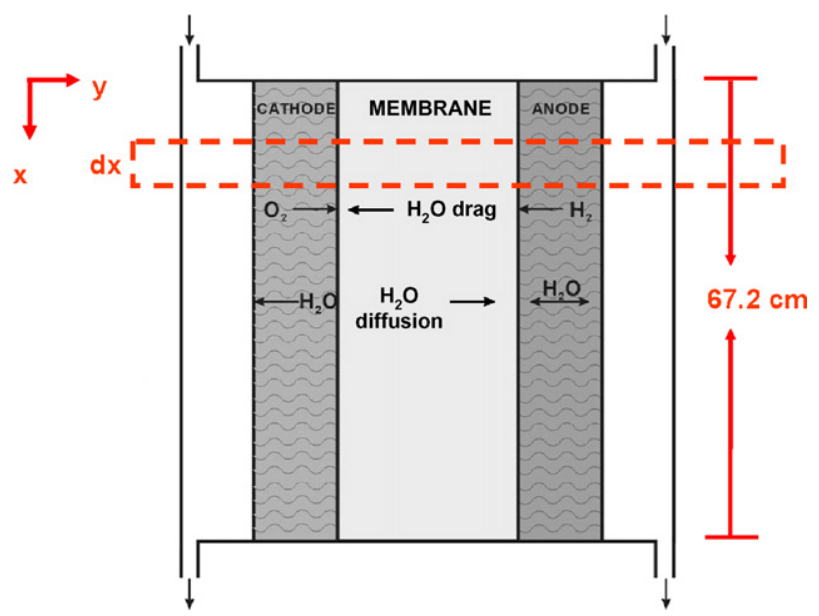

Fig. 3. Process representation for modeling with corresponding dimensions. 


\subsection{Modeling equations}

According to the above assumptions, the governing equations can then be derived. The steady-state changes in the molar flow rates of reactant gases at which hydrogen and oxygen are consumed and water is generated, are determined by Faraday's law. For each section, the consumption of hydrogen and oxygen in the flow direction ( $x$-direction) is:

$$
\begin{aligned}
\frac{\mathrm{d} M_{\mathrm{H}_{2}}(x)}{\mathrm{d} x} & =-\frac{h}{2 F} I(x) \\
\frac{\mathrm{d} M_{\mathrm{O}_{2}}(x)}{\mathrm{d} x} & =-\frac{h}{4 F} I(x)
\end{aligned}
$$

where $M$ is the molar flow rate and is a function of coordinate $x$, $h$ is the channel width, $F$ is Faraday's constant, and $I$ is the local current density along the channel.

The production molar rates of water vapor at the anode and cathode are:

$$
\begin{aligned}
\frac{\mathrm{d} M_{\mathrm{w}, \mathrm{a}}^{\mathrm{v}}(x)}{\mathrm{d} x}= & -\frac{k_{\mathrm{c}} h d}{R T_{\text {cell }}}\left\{\frac{M_{\mathrm{w}, \mathrm{a}}^{\mathrm{v}}(x)}{M_{\mathrm{w}, \mathrm{a}}^{\mathrm{v}}(x)+M_{\mathrm{H}_{2}}(x)} P_{\mathrm{a}}(x)\right. \\
& \left.-P_{\mathrm{w}}^{\mathrm{sat}}\left(T_{\text {cell }}\right)\right\}-\frac{h}{F} I(x) \cdot \alpha \\
\frac{\mathrm{d} M_{\mathrm{w}, \mathrm{c}}^{\mathrm{v}}(x)}{\mathrm{d} x}= & -\frac{k_{\mathrm{c}} h d}{R T_{\mathrm{cell}}}\left\{\frac{M_{\mathrm{w}, \mathrm{c}}^{\mathrm{v}}(x)}{M_{\mathrm{w}, \mathrm{c}}^{\mathrm{v}}(x)+M_{\mathrm{O}_{2}}(x)} P_{\mathrm{c}}(x)-P_{\mathrm{w}}^{\mathrm{sat}}\left(T_{\mathrm{cell}}\right)\right\} \\
& +\frac{h}{F} I(x) \cdot \alpha+\frac{h}{2 F} I(x)
\end{aligned}
$$

where the first term on the right-hand-side (RHS) is condensation or evaporation of water. The second term on the RHS represents the net migration of water molecules across the membrane and the third term on the RHS of Eq. (4) denotes the generation of water by reaction. Here, $k_{\mathrm{c}}$ represents the condensation rate constant, $d$ is the channel height, $R$ denotes the gas constant, $T_{\text {cell }}$ is the cell temperature, $P_{\mathrm{a}}$ is the anode pressure, $P_{\mathrm{c}}$ is the cathode pressure, $P_{\mathrm{W}}^{\mathrm{sat}}$ is the saturation pressure of water vapor, and $\alpha$ is the net migration of water molecules per proton across the membrane. This net migration is affected by three water transport mechanisms: electro-osmotic drag, backdiffusion, and convection.

Consider the pressure drop along the gas channel. It can be expressed as:

$$
\frac{\mathrm{d} P_{\mathrm{k}}(x)}{\mathrm{d} x}=4 f_{\mathrm{k}}(x) \frac{1}{D_{\mathrm{e}}} \frac{v_{\mathrm{k}}^{2}(x)}{2 g_{\mathrm{c}}} \rho_{\mathrm{k}}(x) \frac{1}{101325}, \quad \mathrm{k}=\mathrm{a}, \mathrm{c}
$$

where $f_{\mathrm{k}}$ is the friction factor, $D_{\mathrm{e}}$ is the hydraulic diameter, $g_{\mathrm{c}}$ is the conversion factor, $\rho_{\mathrm{k}}$ is the density of the gas mixture, and $v_{\mathrm{k}}$ is the averaged velocity.

To determine the relationship between the cell voltage and the current density, the actual cell voltage can be derived by Nernst equation, Butler-Volmer equation, and Ohm's law as shown in Eq. (6). It deviates from the equilibrium potential because of irreversible losses. The losses are contributed from: (1) activation polarization, (2) ohmic polarization, and (3) concentration polarization. Thus, we have [16]:

$$
\begin{aligned}
V_{\text {cell }}(x)= & V_{\mathrm{oc}}+\frac{R T_{\text {cell }}}{2 F} \ln \left(\frac{P_{\mathrm{H}_{2}, \mathrm{~s}}(x) P_{\mathrm{O}_{2}, \mathrm{~s}}(x)^{0.5}}{P_{\mathrm{w}, \mathrm{c}, \mathrm{s}}(x)}\right) \\
& -\frac{R T_{\text {cell }}}{F} \ln \left(\frac{I(x)}{I_{\mathrm{o}} P_{\mathrm{O}_{2}, \mathrm{~s}}(x)}\right)-\frac{I(x) t_{\mathrm{m}}}{\sigma_{\mathrm{m}}}
\end{aligned}
$$

where $V_{\text {cell }}$ is the cell voltage, $V_{\mathrm{oc}}$ is the open circuit potential, and $I_{\mathrm{O}}$ is the exchange current density. Note that $I_{\mathrm{O}}$ in electrochemical reactions is similar to the rate constant in chemical reactions and it is generally expressed in Arrhenius from ref. [17]. $t_{\mathrm{m}}$ is the membrane thickness, and $\sigma_{\mathrm{m}}$ is the membrane conductivity. The averaged current density can be computed from:

$I_{\text {avg }}=\frac{1}{L} \int_{0}^{L} I(x) \mathrm{d} x$

where $I_{\text {avg }}$ is the averaged current density and $L$ is the channel length.

Due to the cell temperature uniformity within a PEM fuel cell, energy balance equations are negligible in this system. Table 1 summarizes the aforementioned equation notations used in this model.

\subsection{Equation solving procedure}

Eqs. (1)-(6) can be solved sequentially by using an implicit integrator and the code is programmed in FORTRAN. There is only one degree-of-freedom in this system: the cell voltage. In order to solve this set of equations for each section, an iterative procedure is taken. For each section, the cell voltage is set to a constant and then the local current density is solved iteratively until the calculated cell voltage approaches the preset value. Therefore, the algorithm consists of the following steps:

(1) Set the cell voltage $\left(V_{\text {cell }}\right)$.

(2) Compute the outlet pressures $\left(P_{\mathrm{a}}, P_{\mathrm{c}}\right)$ at the anode and cathode (Eq. (5)).

(3) Estimate the local current density ( $\left.I^{\text {estimated }}\right)$.

(4) Calculate the outlet flow rates of hydrogen and oxygen $\left(M_{\mathrm{H}_{2}}, M_{\mathrm{O}_{2}}\right)$ (Eqs. (1) and (2)).

(5) Estimate the transfer coefficient ( $\alpha^{\text {estimated }}$ ) (Table 1).

(6) Compute the outlet flow rates of water vapor at the anode and cathode $\left(M_{\mathrm{w}, \mathrm{a}}^{\mathrm{v}}, M_{\mathrm{w}, \mathrm{c}}^{\mathrm{v}}\right)$ (Eqs. (3) and (4)) to meet the mass balances by adjusting the transfer coefficient $(\alpha)$.

(7) Adjust the estimate of the local current density until the cell voltage approaching the set value.

(8) Repeat steps 1-7 for the amended cell voltage $\left(V_{\text {cell }}\right)$.

\section{Results and discussions}

\subsection{Regression and validation}

At the modeling stage, a first principle model has been constructed and then modeling and design parameters can be 
Table 1

Variables and corresponding equations

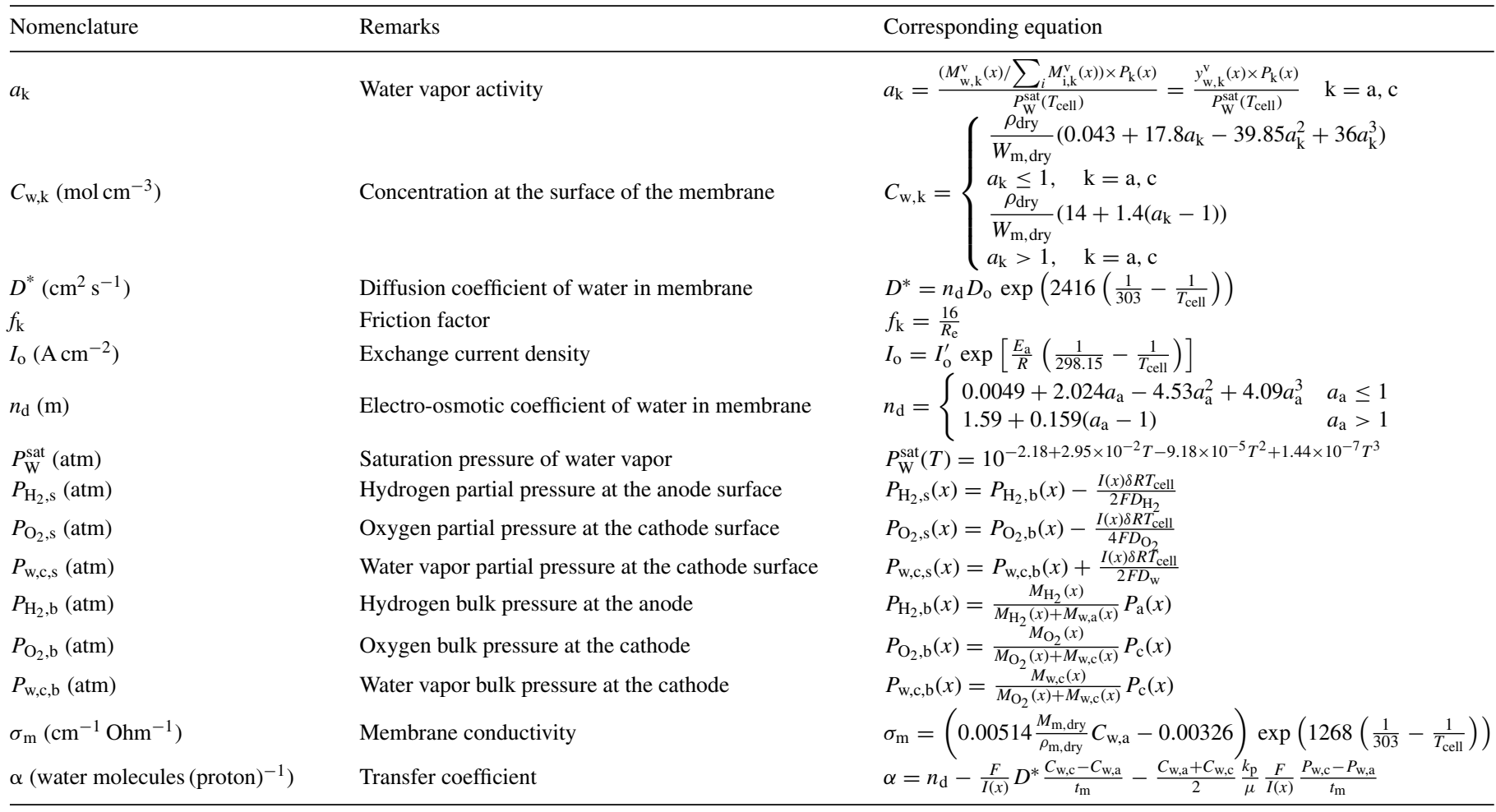

identified via regression from the experimental data. First of all, the optimization equation with $n$ data sets and $r$ experimental data points per experimental condition can be formulated as:

$\min _{x} f(x)=\sum_{i=1}^{n} \sum_{j=1}^{r}\left(I_{\mathrm{avg}, j i}^{\text {calculated }}-I_{\mathrm{avg}, j i}^{\mathrm{exp}}\right)^{2}$,

$x \in\left\{V_{\mathrm{oc}}, t_{\mathrm{m}}, E_{\mathrm{a}}, \delta\left(T_{\mathrm{cell}, i}\right)\right\}$

In this work, four sets of experimental data with the cell operating at temperatures of $50,60,70$, and $80^{\circ} \mathrm{C}$ are used for the regression, and an optimization run takes about 2 min using IMSL (DBCONF) in FORTRAN. The two design parameters, open circuit potential $\left(V_{\mathrm{oc}}\right)$ and membrane thickness $\left(t_{\mathrm{m}}\right)$, and the two modeling parameters, activation energy $\left(E_{\mathrm{a}}\right)$ and diffusion layer thickness $(\delta)$, are obtained by minimizing the square errors between data and predicted values. The results are summarized

Table 2

Design parameters and modeling parameters

\begin{tabular}{lll}
\hline Design parameters & Value & Remarks \\
\hline$V_{\mathrm{oc}}(\mathrm{V})$ & 0.918 & Open circuit potential \\
$t_{\mathrm{m}}(\mathrm{cm})$ & 0.0129 & Membrane thickness
\end{tabular}

\begin{tabular}{lll} 
Modeling parameters & Value & Remarks \\
\hline$E_{a}\left(\mathrm{~J} \mathrm{~mol}^{-1}\right)$ & 4758 & Activation energy \\
$\delta\left(T_{\text {cell }}=50^{\circ} \mathrm{C}\right)(\mathrm{cm})$ & $6.14 \times 10^{-6}$ & Diffusion layer thickness \\
$\delta\left(T_{\text {cell }}=60^{\circ} \mathrm{C}\right)(\mathrm{cm})$ & $6.65 \times 10^{-6}$ & Diffusion layer thickness \\
$\delta\left(T_{\text {cell }}=70^{\circ} \mathrm{C}\right)(\mathrm{cm})$ & $5.69 \times 10^{-6}$ & Diffusion layer thickness \\
$\delta\left(T_{\text {cell }}=80^{\circ} \mathrm{C}\right)(\mathrm{cm})$ & $5.55 \times 10^{-6}$ & Diffusion layer thickness \\
\hline
\end{tabular}

in Table 2. Fig. 4 shows that reasonably good predictions can be obtained. However, one of the modeling parameters, diffusion layer thickness, which is used to describe the effect of concentration overpotential is not clearly identified. It is reasonable to correlate the oxygen molar flow rate with the diffusion layer thickness due to the mass transport phenomena. Fig. 5 clarifies a linear relationship between the average oxygen molar flow rate and the diffusion layer thickness for an improved fitting of the experimental data. The averaged oxygen molar flow rate is computed for a specific $I-V$ curve for cell voltage between 0.6 and $0.7 \mathrm{~V}$. The diffusion layer thickness is an explicit function of average oxygen molar flow.

$\delta(\mathrm{cm})=1.21 \times 10^{-5}-0.08\left(M_{\mathrm{O}_{2}}\right)_{\mathrm{avg}}\left(\mathrm{mol} \mathrm{s}^{-1}\right)$

In the subsequent computation, the diffusion layer thickness is adjusted according to Eq. (11) as the operating condition changes. Once the $I-V$ curve becomes available, one can generate the corresponding current density and power curve, Fig. 6 (for $I-P$ curve for a given temperature), which is useful for process operation as the power demand changes.

Next, the experimental data on different anode/cathode pressures, feed stoichiometric ratios, and humidification temperatures are tested on this predictive model while keeping the other operating variables at nominal values. As can be seen in Fig. 7, the predictive model captures the process trends well for various operating conditions. It should also be emphasized here that the predictive model provides reasonably good behavior without any adjustable parameter. 
(A) $\mathrm{T}_{\text {cell }}=50^{\circ} \mathrm{C}$

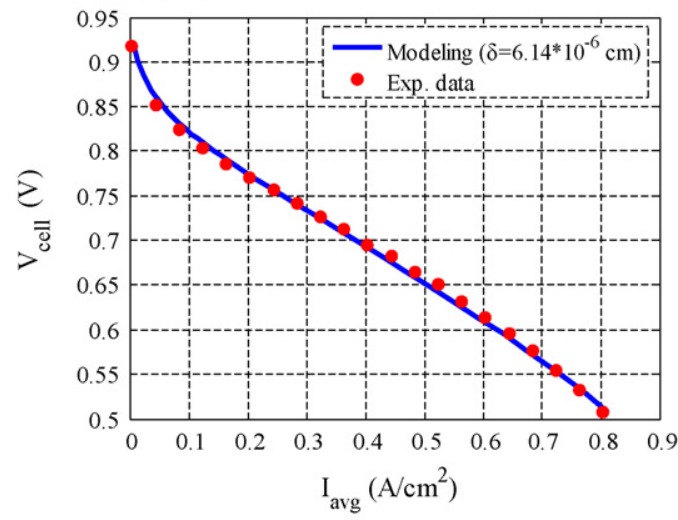

(C) $\mathrm{T}_{\text {cell }}=70^{\circ} \mathrm{C}$

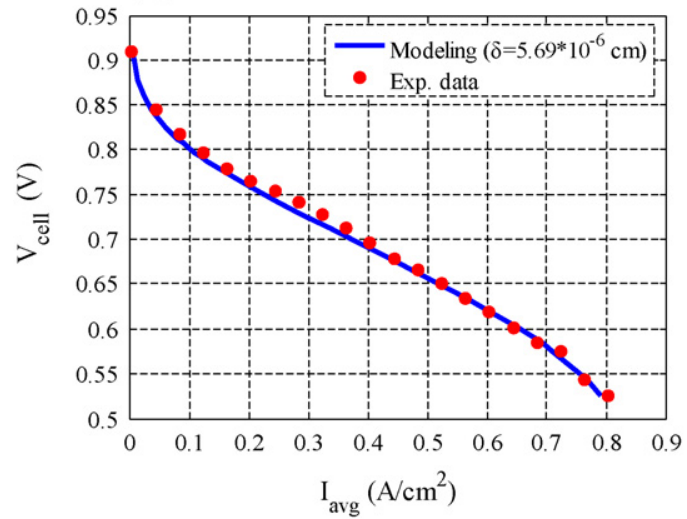

(B) $\mathrm{T}_{\text {cell }}=60^{\circ} \mathrm{C}$

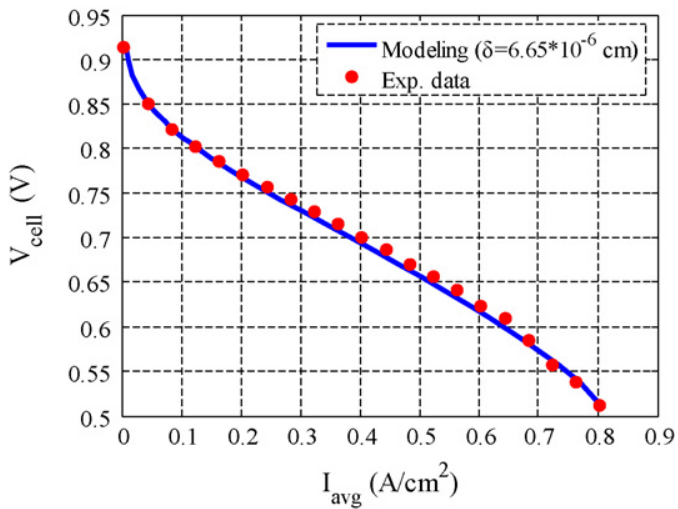

(D) $\mathrm{T}_{\text {cell }}=80^{\circ} \mathrm{C}$

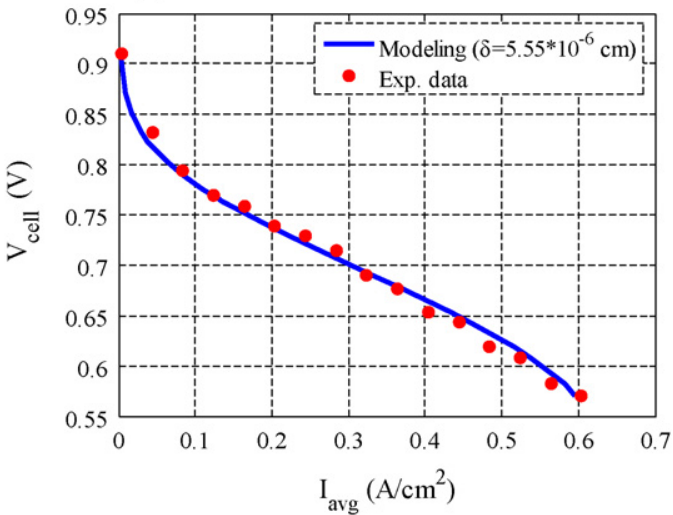

Fig. 4. Model prediction and experimental data for four different cell temperatures with $\mathrm{H}_{2} /$ air flow rate $=1.5 \mathrm{X} / 2.5 \mathrm{X}$ Stoich., $\mathrm{H}_{2} /$ air humidification temperatures $=70^{\circ} \mathrm{C} / 70^{\circ} \mathrm{C}$, and $\mathrm{H}_{2} /$ air pressures $=1 \mathrm{~atm} / 1 \mathrm{~atm}$.

\subsection{Sensitivity analysis}

Once the steady-state model is available, it is possible to predict the behavior of a single PEM fuel cell. At the application level, operating at the peak power (maximum in Fig. 6) should be

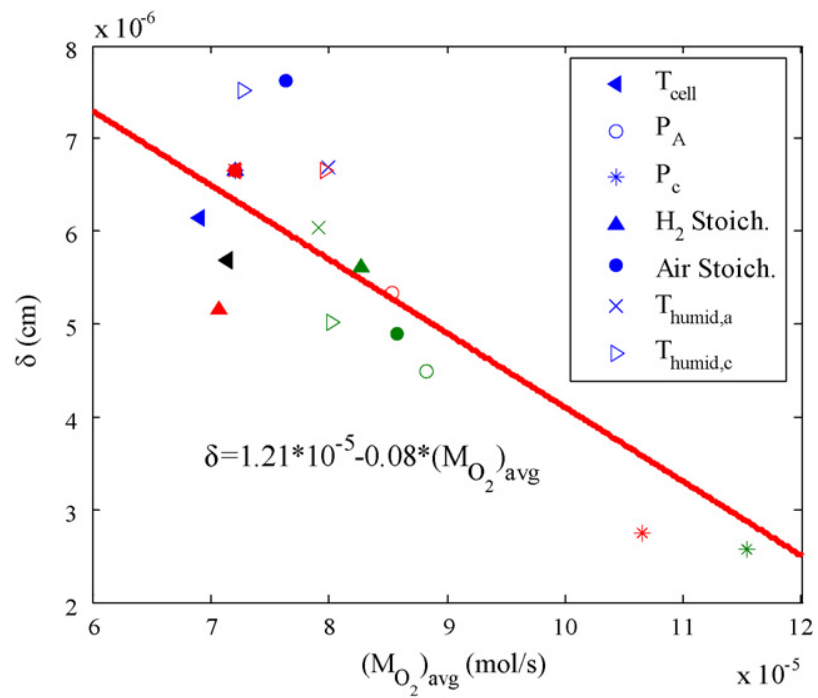

Fig. 5. The correlation between the diffusion layer thickness and the averaged oxygen molar flow rate computed from the range of cell voltage between 0.6 and $0.7 \mathrm{~V}$. avoided because it results in sign reversal as the current density varies. In terms of process control, this will lead to instability if an integral action is employed in the controller. Therefore, a common practice is to set the operating cell potential to the range of $0.6-0.7 \mathrm{~V}[18,19]$. It is obvious that the selected cell

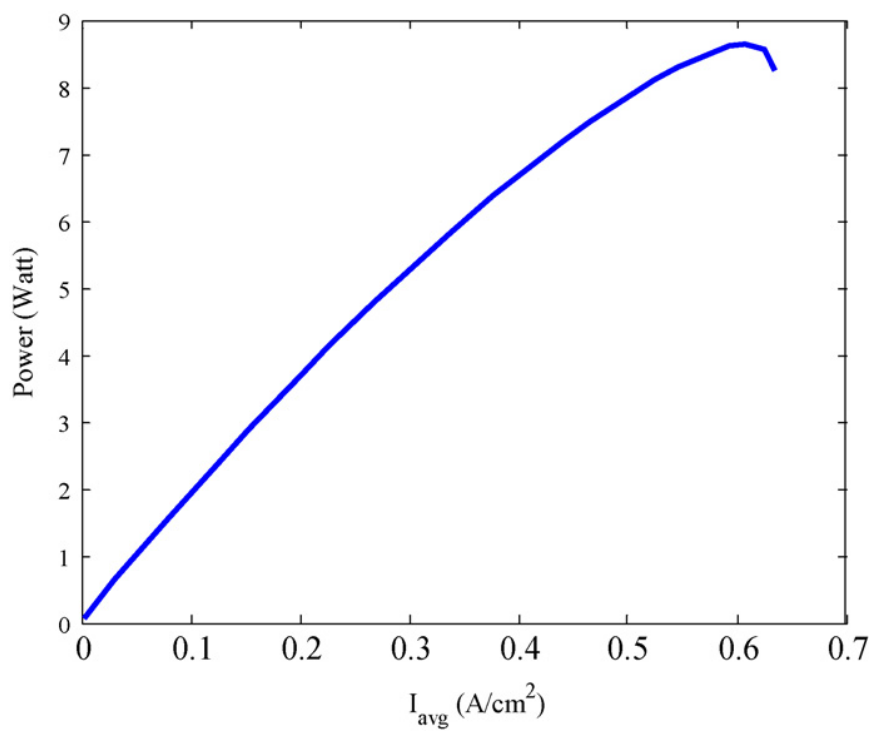

Fig. 6. The power output vs. average current density at a given temperature of $80^{\circ} \mathrm{C}$. 
potential depends on the desired fuel cell size and power demand for various applications. Without loss of generality, we simply set the nominal operating point to $0.65 \mathrm{~V}$ as shown in Fig. 8 . At the operating level, the power output is often adjusted as the load varies. Thus, it is important to identify dominant process variables [20] to meet the load demand via feedback control. It is well known that the performance of the PEM fuel cell is influenced by many operating variables such as: the fuel cell temperature, the stoichiometric ratios of the reactants, the anode and cathode pressure, and the humidification temperatures of the reactants at the anode and cathode. In this section, the effects of these variables on the $I-V$ curve and consequently the power
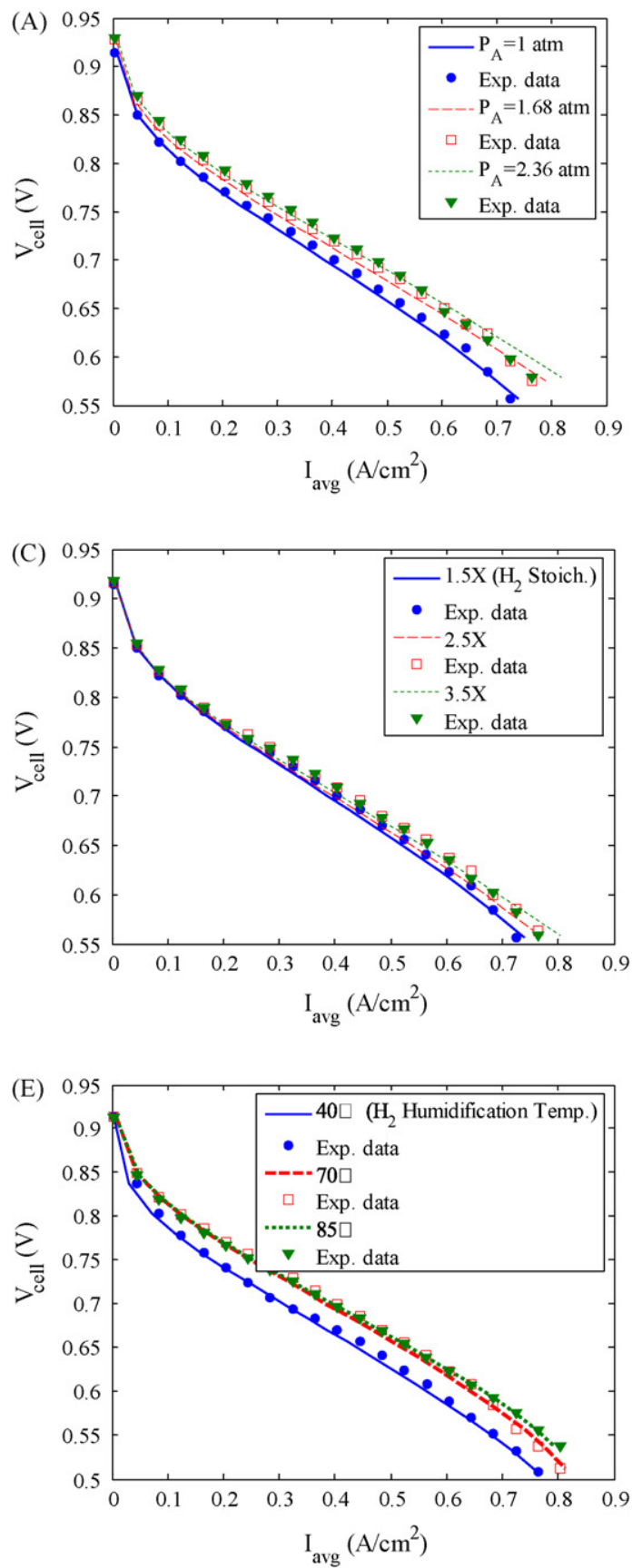

output will be explored. All the changes are expressed in terms of percentage of the full operating range. The full range (transmitter span) for the cell temperature is $50^{\circ} \mathrm{C}$ (from 30 to $80^{\circ} \mathrm{C}$ ), for the stoichiometric ratio of hydrogen and air it is $2.5 \mathrm{X}$ (from 1 to $3.5 \mathrm{X}$ ), for the anode and cathode pressure, it is $1.36 \mathrm{~atm}$ (from 1 to $2.36 \mathrm{~atm}$ ), and for the humidification temperature it is $60^{\circ} \mathrm{C}$ (from 25 to $85^{\circ} \mathrm{C}$ ).

\subsubsection{The fuel cell temperature}

Fig. 9 shows how power output varies due to changes of $\pm 20 \%$ in the cell temperatures compared with the base case at a fixed cell potential of $0.65 \mathrm{~V}$. A $20 \%$ increase in the cell
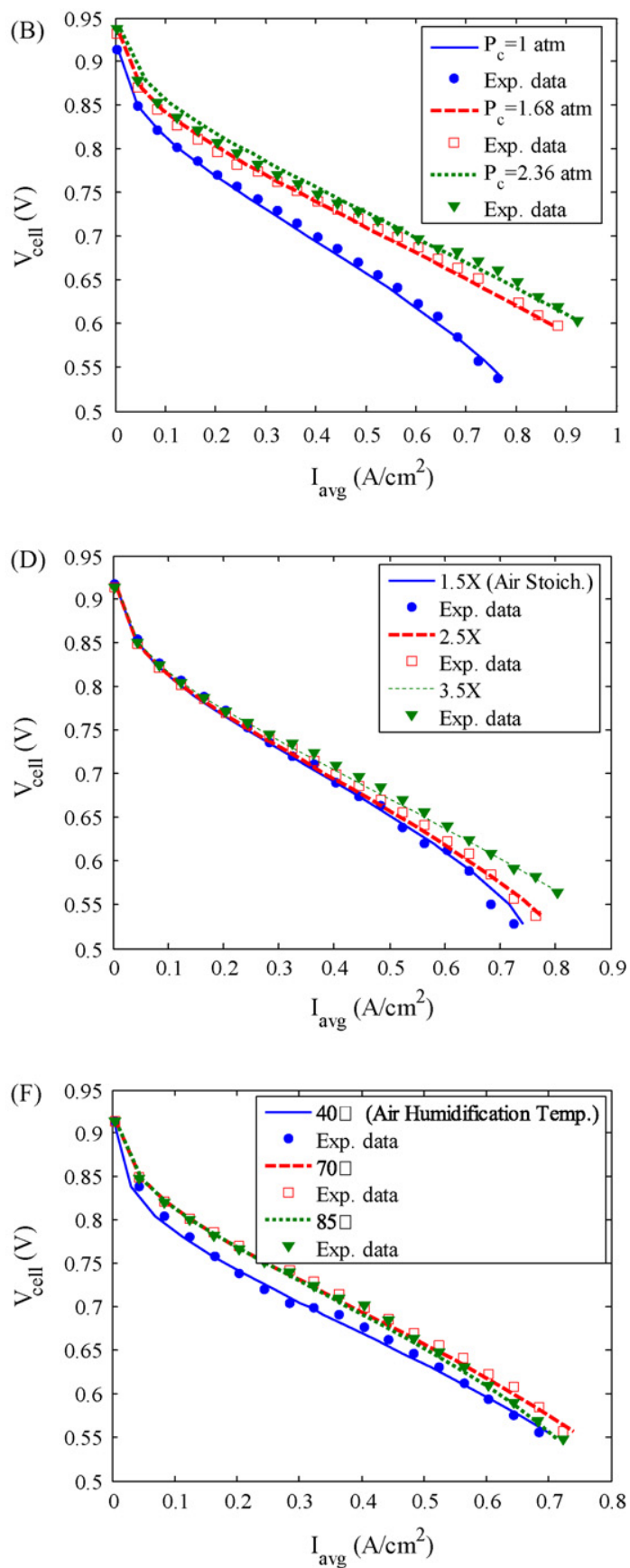

Fig. 7. Model predictions and experimental data at a fixed cell temperature of $60^{\circ} \mathrm{C}$ when varying: (A) anode pressure, (B) cathode pressure, (C) hydrogen stoichiometric ratio, (D) air stoichiometric ratio, (E) hydrogen humidification temperature, and (F) air humidification temperature. 


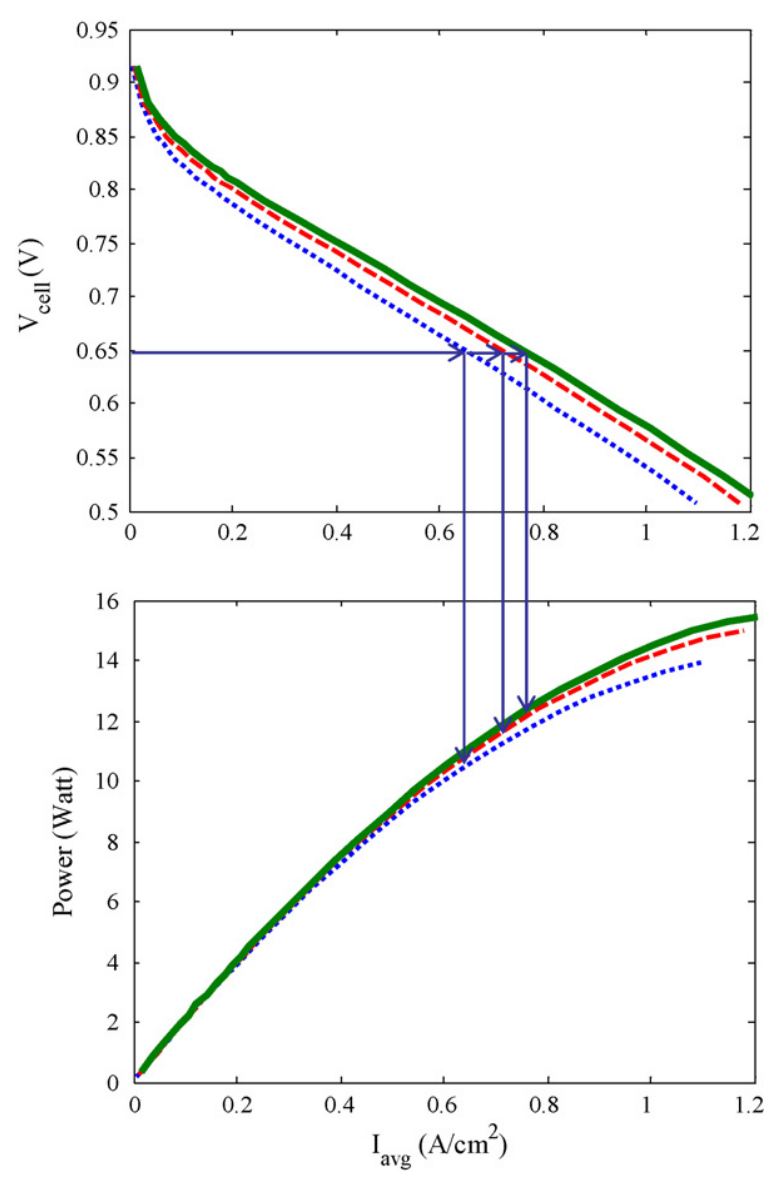

Fig. 8. Corresponding power output (from current-power $(I-P)$ curve) when cell potential fixed to $0.65 \mathrm{~V}$ in the $I-V$ curve.

temperature leads to an $8 \%$ increase in the power output. A decrease of $20 \%$ in the cell temperature reduces the power output by $20 \%$. The reason is that a higher cell temperature causes a higher exchange current density, which facilitates the rate of electrochemical reaction and significantly improves mass transport properties.

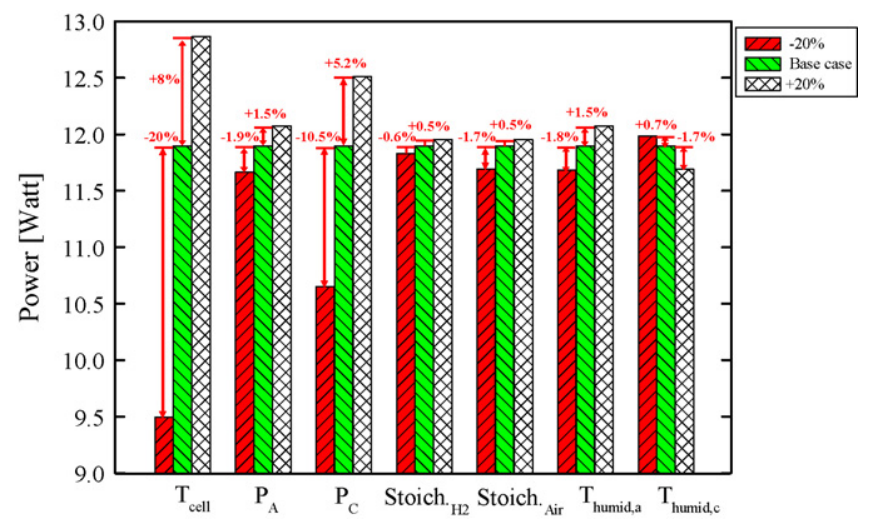

Fig. 9. Sensitivity of power output for $\pm 20 \%$ (of full range) changes in various operating variables: cell temperature $\left(T_{\text {cell }}\right)$, anode/cathode pressure $\left(P_{\mathrm{a}}\right.$ and $\left.P_{\mathrm{c}}\right)$, stoichiomertic ratios of hydrogen and air (Stoich. ${ }_{\mathrm{H}_{2}}$ and Stoich.Air), humidification temperatures at the anode and cathode ( $T_{\text {humid,a }}$ and $T_{\text {humid,c }}$ ) at a fixed cell potential of $0.65 \mathrm{~V}$.

\subsubsection{The anode and cathode pressures}

The effects of the anode and cathode pressure changes $( \pm 20 \%)$ to the power outputs are also shown in Fig. 9. An increase of $20 \%$ in the cathode pressure leads to a $5.2 \%$ increase in the power output, as compared to an increase of $20 \%$ in the anode pressure, which leads to a $1.5 \%$ increase in the power output. A decrease of $20 \%$ in the cathode pressure leads to a decrease of $10.5 \%$ in the power output, as compared to a decrease of $20 \%$ in the anode pressure, which leads to a $1.9 \%$ decrease in the power output. It can obviously be seen that the variations in the cathode pressure are more consequential than those in the anode pressure. The reason is a higher cathode pressure leads to a higher oxygen concentration, which promotes power generation (i.e., reaction). Also the rate of the electrochemical reaction is determined by oxygen reduction at the cathode.

\subsubsection{The stoichiometric ratios of the reactants}

Given a cell potential of $0.65 \mathrm{~V}$, a $20 \%$ decrease in air stoichiometry can decrease the cell performance by $1.7 \%$ (three times that of the hydrogen stoichiometry). As shown in Fig. 9, a higher air stoichiometric ratio (the increase in the ratio of true air flow rate to theoretical air flow rate) gives a better cell performance. There are two possible explanations. First, a higher air feed flow rate results in a higher oxygen concentration and this subsequently increases the reaction rate. Second, a higher air flow rate helps the removal of water which can cause flooding at the cathode channel. On the contrary, $\pm 20 \%$ changes in the stoichiometric ratio of hydrogen result in little variation in the cell performance. The reason for that is the reaction rate of hydrogen oxidation is relatively fast (not a rate limiting step).

\subsubsection{The humidification temperatures of the reactants at the anode and cathode}

Fig. 9 shows that when the cathode humidification temperature increases by $20 \%$, the power output is reduced by $1.7 \%$. The reason is that there are three sources of water at the cathode channel. One is water transferred from the anode side to the cathode side, the second is water generated from the reaction, and the third is water coming from the cathode inlet. If the inlet stream carries excessive amounts of water vapor, it will eventually cause flooding at the cathode channel, and then lead to cell operation failure. The anode, on the other hand, supplies water vapor to boost reaction. Thus, a $20 \%$ increase in the humidification temperature at the anode will give better cell performance, and it results in a $1.5 \%$ increase in power output. A $20 \%$ decrease reduces the power output by $1.8 \%$. This is because water vapor carried from the anode inlet is dragged through the membrane by migrating hydrogen protons and helps to promote reaction. Otherwise, the membrane at the anode side will be dehydrated and then the membrane resistance will increase and cause the cell operation failure.

\subsubsection{Summary}

In summary, the fuel cell temperature, the cathode pressure, the humidification temperature at the anode, and the stoichiometric ratios of air are the dominant process variables in the PEM 

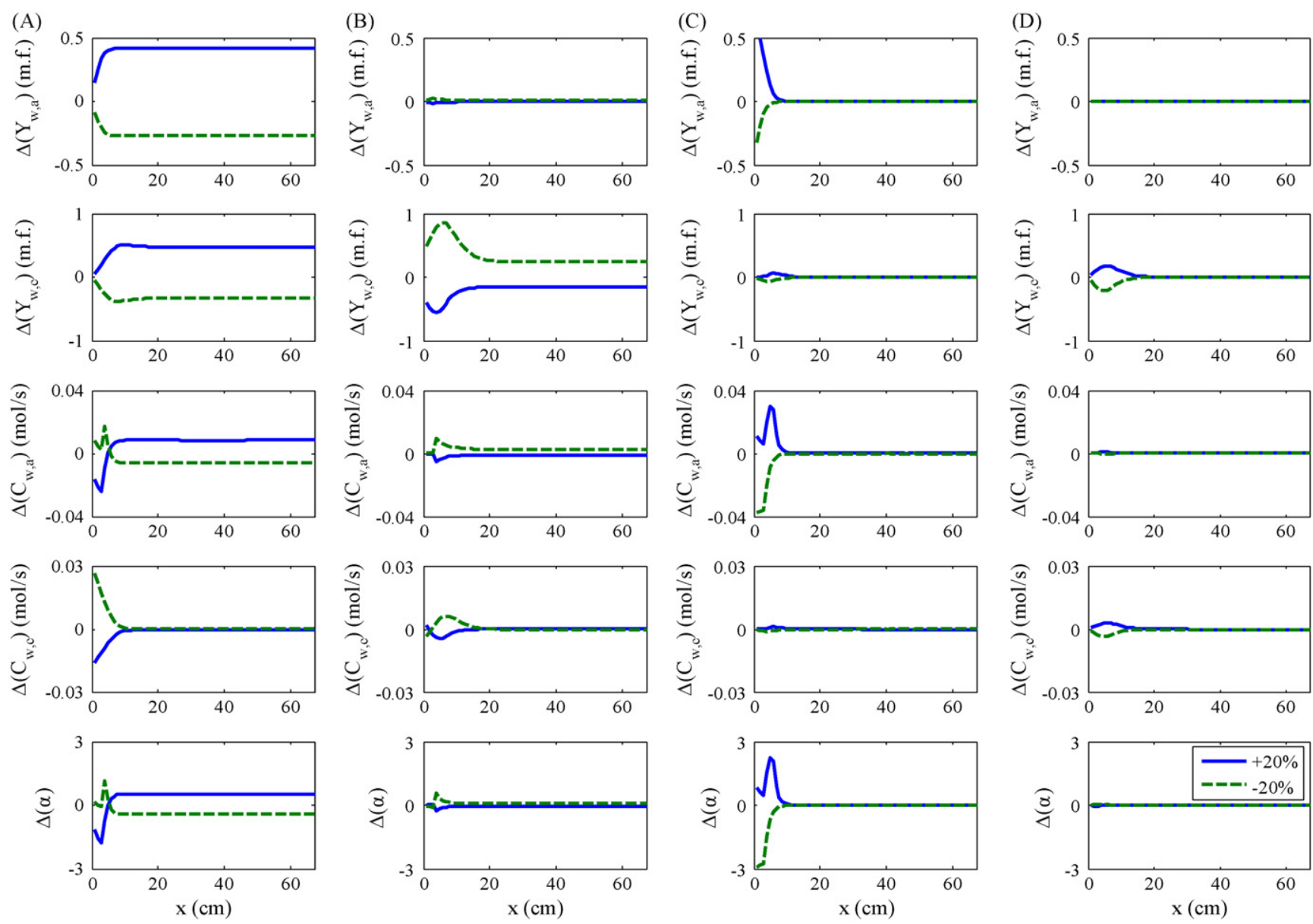

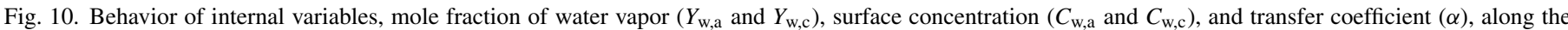

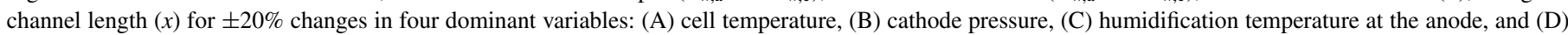
stoichiometric ratio of air.

fuel cell system. The heart of a fuel cell is a membrane electrode assembly, which means the inherent water transfer coefficient can have a significant effect on the fuel cell performance.

The internal variables along the $x$-direction (Fig. 10) provide physical insight to the effects of process variables. Fig. 10 shows the effects of dominant process variables on the following internal variables along the $x$-direction. They are mole fraction of water vapor $\left(Y_{\mathrm{w}, \mathrm{a}}\right.$ and $\left.Y_{\mathrm{w}, \mathrm{c}}\right)$, surface water concentration $\left(C_{\mathrm{w}, \mathrm{a}}\right.$ and $\mathrm{C}_{\mathrm{w}, \mathrm{c}}$ ), and transfer coefficient $(\alpha)$. The cell temperature has the greatest effect on the transfer coefficient, followed by the cathode pressure. It is also clear that the humidification temperature at the anode and the stoichiometric ratios of air do not significantly affect the transfer coefficient.

\subsection{Nonlinearity}

In general, a higher cell temperature results in higher cell performance. However, if the cell temperature is too high it will generate too much heat and water as by-products, both are unfavorable to the cell operation. As shown in Fig. 2, when the cell temperature increases from 70 to $80^{\circ} \mathrm{C}$, the trend of the $I-V$ curves changes. That implies that we have non-monotonic behavior for cell temperature changes.
Fig. 11(A) shows that when the operating temperature goes up from 54 to $70^{\circ} \mathrm{C}$, the power increases. However, a further increase in the operating temperature (from 70 to $78^{\circ} \mathrm{C}$ ) leads to a decrease in the power output of $22 \%$. Thus, we have an optimal operating temperature for maximum power output. The trade-off comes from two competing factors. One is the effect of temperature on the exchange current density $\left(I_{0}\right.$, Fig. 11(B)). A higher operating temperature will give a higher exchange current density, and that, in turn, facilitates the electrochemical reaction. The other is the water concentration at the cathode surface of the membrane, also shown in Fig. 11(B). If the surface water concentration is too low, water vapor transferred from the anode side will increase. At the same time, water at the cathode side is also generated by the reaction. It should be noted that too much water would cause flooding at the cathode and then decrease the cell performance. It is therefore essential to control the cell operating temperature in order to maintain the desired power output.

The non-monotonic behavior is not only observed in the temperature-power curve, but more common situation, in the current-power curve. This has important implication in process control, because the process gain (between $P$ and $I$ ) may change sign. Thus, a reasonable description of the $I-V$ curves at different 

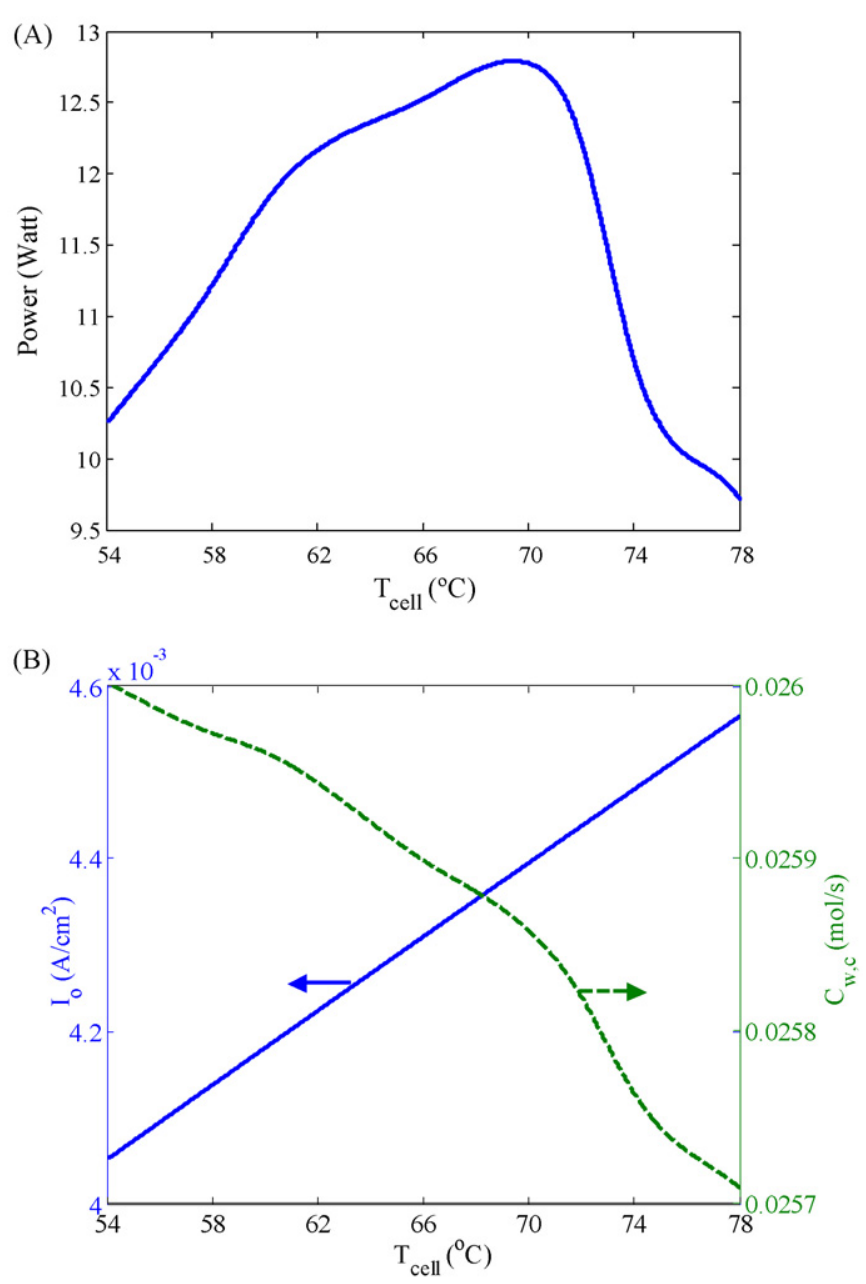

Fig. 11. (A) Power output levels for different cell temperatures from 54 to $78^{\circ} \mathrm{C}$ and (B) the exchange current density and the surface water concentration at the cathode vs. the cell temperatures.

operating conditions is helpful to devise gain-schedule control, and more importantly, to avoid possible unstable operation.

\section{Conclusions}

In this study, an experimental setup was constructed and experiments were performed on a single PEM fuel cell at the ITRI Hsinchu facility. A first principle one-dimensional model is constructed and a solution procedure is formulated. Based on the temperature experimental data, design and modeling param- eters are identified via constraint optimization. The predictive model gives reasonably good behavior description as operating conditions (e.g., fuel cell temperature, anode pressure, cathode pressure, hydrogen stoichiometric ratio, air stoichiometric ratio, hydrogen humidification temperature, and air humidification temperature) change. Next, the prediction capability of the model is illustrated via sensitivity analyses. The simulation results show that the following process variables, fuel cell temperature, cathode pressure, air feed stoichiometric ratio, and anode humidification temperature, are effective in changing the $I-V$ curves and, subsequently, power output.

\section{Acknowledgements}

This work was supported in part by National Science Council of Taiwan. We also thank Jeffrey D. Ward for insightful comments.

\section{References}

[1] T.E. Springer, T.A. Zawodzinski, S. Gottesfeld, J. Electrochem. Soc. 138 (1991) 2334-2342.

[2] D.M. Bernardi, M.W. Verbrugge, J. Electrochem. Soc. 139 (1992) 2477-2491.

[3] J.S. Yi, T.V. Nguyen, J. Electrochem. Soc. 145 (1998) 1149-1159.

[4] N. Djilali, D.M. Lu, Int. J. Thermal Sci. 41 (2002) 29-40.

[5] J. Ramousse, J. Deseure, O. Lottin, S. Didierjean, D. Maillet, J. Power Sources 145 (2005) 127-416.

[6] T.F. Fuller, J. Newman, J. Electrochem. Soc. 140 (1993) 1218-1225.

[7] T.V. Nguyen, R.E. White, J. Electrochem. Soc. 140 (1993) 2178-2186.

[8] J.S. Yi, T.V. Nguyen, J. Electrochem. Soc. 146 (1999) 38-45.

[9] W.M. Yan, F.L. Chen, H.Y. Wu, C.Y. Soong, H.S. Chu, J. Power Sources 129 (2004) 127-137.

[10] N.P. Siegel, M.W. Ellis, D.J. Nelson, M.R. von Spakovsky, J. Power Sources 128 (2004) 173-184.

[11] S. Dutta, S. Shimpalee, J.W. Van Zee, J. Appl. Electrochem. 30 (2000) $135-146$.

[12] H. Meng, C.Y. Wang, J. Electrochem. Soc. 151 (2004) A358-A367.

[13] S. Um, C.Y. Wang, J. Power Sources 125 (2004) 40-51.

[14] T. Berning, D.M. Lu, N. Djilali, J. Power Sources 106 (2002) 284-294.

[15] H. Ju, H. Meng, C.Y. Wang, Int. J. Heat Mass Transfer 48 (2005) 1303-1315.

[16] J. Golbert, D.R. Lewin, J. Power Sources 135 (2004) 135-151.

[17] A. Parthasarathy, S. Srinivasan, A.J. Appleby, C.R. Martin, J. Electrochem. Soc. 139 (1992) 2530-2537.

[18] F. Barbir, PEM Fuel Cells: Theory and Practice, first ed., Elsevier Academic Press, New York, 2005.

[19] Fuel Cell Handbook, sixth ed., EG\&G Services Parsons, Inc., Science Applications International Corporation, Morgantown, 2002.

[20] J.M. Douglas, Conceptual Process Design, McGraw-Hill, New York, 1988. 